\title{
Recenzja
}

\section{Andrzej Gaca, Zbigniew Witkowski, Podstawy ustroju konstytucyjnego Republiki Wtoskiej, Wydawnictwo Towarzystwo Naukowe Organizacji i Kierownictwa, „Dom Organizatora”, Toruń 2012, ss. 333}

Recenzowana książka stanowi najnowszą monografię, która kompleksowo omawiała ustrój konstytucyjny Włoch. Jest ona dziełem pracowników Wydziału Prawa UMK w Toruniu. Jeden ze współautorów książki - prof. Zbigniew Witkowski od wielu lat zajmuje się zagadnieniami współczesnego konstytucjonalizmu Republiki Włoch i posiada w tej dziedzinie imponujący dorobek naukowy, on też jest Autorem siedemnastu, z osiemnastu rozdziałów książki. Z kolei prof. Andrzej Gaca jest uznanym historykiem ustrojów, a jego autorstwa jest rozdział poświęcony historii ustroju Włoch do ich zjednoczenia. Ustrój polityczny Italii w ostatnim okresie podlegał dynamicznym przemianom, stąd też poprzednia pozycja prof. Z. Witkowskiego Ustrój konstytucyjny współczesnych Włoch w aktualnej fazie jego przemian 1989-2004, przedstawiająca badania nad ustrojem Włoch z uwagi na upływ ośmiu lat od jej publikacji częściowo została zdezaktualizowana. Problematyka na której skoncentrowano się w książce Podstawy ustroju konstytucyjnego Republiki Włoskiej jest jak najbardziej aktualna i bardzo ważna, albowiem rozważania dotyczą również najnowszych wydarzeń na scenie politycznej Włoch, które dotychczas w literaturze polskojęzycznej nie były poddane odrębnej analizie. Dodać też należy, iż przygotowanie publikacji przedstawiającej w tak kompleksowy sposób historię ustroju Republiki Włoskiej, aż do współczesności stanowiło zapewne niełatwe zadanie badawcze.

Za poprawną uznać należy strukturę pracy, zarówno z punktu widzenia kolejności, jak i merytorycznej zawartości poszczególnych rozdziałów. Książka składa się z osiemnastu rozdziałów różnej objętości, z których rozdział I stanowi wprowadzenie, a rozdział XVIII zamykają uwagi końcowe. Dodatkowym atutem pozycji jest druga część książki, którą stanowi dokumentacja w postaci aneksu, zawierającego faktograficzne zestawienia, przedstawiające ważne zagadnienia związane $\mathrm{z}$ historią konstytucyjnej Ita- 
lii, a także tabelaryczne ujęcie przedstawiające wykaz kadencji najważniejszych organów w państwie.

Monografię otwiera stanowiący wprowadzenie rozdział I, który zawiera informacje na temat sytuacji demograficznej państwa i społeczeństwa włoskiego, przedstawia pozycję Włoch na arenie międzynarodowej, jak również omawia podstawowe problemy polityczne i społeczne współczesnej Italii. Obok analizy sfery instytucjonalnej szeroko przedstawiono w tej części książki także aktualną scenę polityczną Włoch.

W rozdziale II, mającym charakter analityczny, zawarto zagadnienia dotyczące flagi i barwy, godła i hymnu Republiki Włoskiej, a także języka włoskiego i innych charakterystycznych symboli tego państwa. Problematyka ta często niesłusznie pomijana jest $\mathrm{w}$ monografiach dotyczących ustrojów konstytucyjnych państw współczesnych. Najciekawsze rozważania w dalszej części tego rozdziału dotyczą szczególnych związków historycznych Włoch i Polski. Analizując kontakty polsko-włoskie Autor nie zapomniał wspomnieć również o faktach bardzo istotnych, lecz długo trzymanych w tajemnicy.

Kolejne dwa rozdziały książki - rozdział III i rozdział IV rozpoczynają zasadniczą część recenzowanej książki tj. stanowią opis historyczny przemian ustroju politycznego Włoch od okresu państwa frankońskiego aż do proklamowania Narodzin Republiki i wejścia w życie Konstytucji z 1947 r. Problematyka ta została przedstawiona w książce bardzo szczegółowo i stanowi obszerny jej fragment. Na szczególną uwagę zasługuje rozdział III stanowiący zarys ustroju politycznego Włoch do zjednoczenia Italii, którego autorem jest prof. A. Gaca. Następny rozdział IV przedstawia dalszą historię konstytucjonalizmu we Włoszech - od czasu zakończenia II wojny światowej do proklamowania Narodzin Republiki i wejścia w życie Konstytucji z 1947 r. Kolejny rozdział V poświęcony jest z kolei charakterystyce Konstytucji z dnia 27 grudnia 1947 r. oraz podstawom ustroju politycznego nowego państwa włoskiego. Autor słusznie podkreśla, że konstytucja była dziełem kompromisu sił politycznych reprezentowanych w konstytuancie, a głównym spoiwem najważniejszych partii politycznych w tamtym okresie był krytyczny stosunek do przeszłości politycznej państwa. W rozdziale tym szczegółowo omówiono systematykę konstytucji, poddano analizie tryb uchwalania i zmiany konstytucji oraz przedstawiono najważniejsze zmiany wprowadzone do konstytucji do czasów współczesnych. 
Rozdział VI koncentruje się na zagadnieniach związanych z systemem praw obywatelskich określonych konstytucyjnie. Uzupełnieniem tych rozważań powinien być rozdział XIII, analizujący system ochrony prawnej i gwarantowania praw obywatelskich. Dla jasności wywodu bardziej przejrzyste byłoby umieszczenie tych dwóch rozdziałów obok siebie. Zdaniem recenzującego przedstawiony w książce system praw i wolności obywatelskich ma charakter skrótowy i syntetyczny. Takie ujęcie tematu nie burzy wywodu, i uzasadnione jest tym, że w sferze tej w ostatnich latach nie doszło do żadnych zasadniczych zmian, a problematykę tę autor bardzo szeroko przedstawił w swojej poprzedniej monografii ${ }^{1}$.

Problematyka systemu wyborczego i partyjnego, które we włoskim systemie politycznym pełnią niezwykle istotną rolę, podjęta została $\mathrm{w}$ rozdziale VII opracowania. Najszerzej omówiono przeobrażenia na scenie politycznej Włoch, przedstawiając stanowiska głównych partii politycznych prezentowane $\mathrm{w}$ programach tych partii, a także w wyborach parlamentarnych w 2006 r. i 2008 r. Osobną część rozdziału VII poświęcono przedstawieniu wykazu działających współcześnie, na przełomie lat 2009-2010 partii politycznych. We Włoszech na skutek przeprowadzonego w dniu 18 kwietnia 1993 r. referendum w sprawie zmian prawa wyborczego stworzono system wyborczy kompensacyjny z przewagą jednomandatowych okręgów wyborczych. Należy uznać słuszność argumentacji przedstawionej przez Prof. Z. Witkowskiego, iż zmiany, które zaszły w systemie politycznym Włoch po 1993 r. są niewystarczające, a sytuacji rozbicia partyjnego nie poprawiła ordynacja wyborcza do obu izb parlamentu z dnia 21 grudnia 2005 r. (s. 174). Szkoda jednak, że w rozważaniach dotyczących systemu partyjnego Autor nie odniósł się do ważkiego zagadnienia finansowania partii politycznych.

Kolejne rozdziały książki przedstawiają najważniejsze instytucje we włoskim systemie konstytucyjnym. W rozdziale VIII Autor koncentruje się na charakterystyce struktury i kompetencji naczelnych władz państwa. W rozdziale tym osobną część poświęcono organom władzy ustawodawczej i wykonawczej oraz sądowniczej. Bardzo ważną okolicznością, słusznie podkreśloną przez Autora jest fakt, że Konstytucja Włoch w żadnym ze swoich postanowień nie odwołuje się wprost do zasady trójpodziału władzy, „a na-

Z. Witkowski, Ustrój konstytucyjny współczesnych Włoch $w$ aktualnej fazie jego przemian 1989-2004, Toruń 2004, s. 317-406. 
wet wręcz przeciwnie - zawiera regulacje wykraczające poza trójelementowy schemat podziału władzy"(s. 181).

Kolejny, związany tematycznie z poprzednim, rozdział IX stanowi krótką charakterystykę pozycji Prezydenta Republiki jako organu reprezentującego jedność narodową. W pierwszej części Autor zastanawia się nad rolą i funkcją Prezydenta w strukturze organów państwowych, a także przedstawia zasady wyboru na ten urząd. Druga część rozdziału koncentruje się nad zakresem kompetencji przyznanych prezydentowi. Autor stoi na stanowisku, że Prezydent Republiki dysponuje szerokim zakresem kompetencji, w zakresie reprezentacji państwa i strzeżenia jego jedności, jak i w zakresie gwarantowania konstytucji (s. 200).

W następnym rozdziale (X) przedstawiono instytucję parlamentu Republiki jako instytucji bikameralizmu doskonałego. Autor trafnie zauważa, że parlament we Włoszech pełni kilka charakterystycznych funkcji: ustawodawczych i nie ustawodawczych. Dopełnienie analizowanych zagadnień stanowi rozdział XII, który opisuje procedurę uchwalania ustaw przez parlament, ze szczególnym uwzględnieniem ustawy budżetowej. W rozdziale tym mowa jest również o realizowaniu funkcji ustawodawczej przez rząd (s. 246) i możliwości wydawania przez niego ustaw delegujących i dekretów ustawodawczych. Szkoda, iż cenne uwagi Autora na temat systemu źródeł prawa we Włoszech nie zostały zebrane w oddzielnym rozdziale. Problematyka ta bowiem jest we Włoszech wielce skomplikowana, a jej usystematyzowanie byłoby niewątpliwie dodatkowym atutem opracowania.

Rozdział XI poświęcony jest zagadnieniom pozycji ustrojowej rządu oraz administracji centralnej Republiki. Autor poddaje analizie przepisy dotyczące pozycji ustrojowej rządu, jego struktury i zasad funkcjonowania. Prof. Z. Witkowski wskazuje na złożoność problemów pozostających w kompetencji Rady Ministrów, a także na istnienie ciał i urzędów o charakterze pomocniczym. Wydaje się, że z uwagi na objętość opracowania Autor świadomie pomija postanowienia dotyczące reformy struktur i zadań Rady Ministrów dokonanej w drodze decreto legislativo z dnia 30 lipca 1999 r., nr 300.

Rozdział XIV, zatytułowany Zasady autonomii lokalnej i decentralizacji administracji jako podstawy struktury terytorialnej państwa prezentuje aktualny problem zmian konstytucyjnych idących w kierunku przyznania coraz większej autonomii regionom Włoch. Autor ze znawstwem charakteryzuje w tym rozdziale instytucje gminy, prowincji i regionów, a także poddaje 
szczegółowej analizie zmiany w strukturze władz lokalnych w poszczególnych jednostkach samorządu terytorialnego. Autor wspomina tutaj również o przeprowadzonej w 2001 r. ważnej reformie wzmacniającej rolę regionów. Parlament Włoch w dniu 5 maja 2009 r. nr 42, uchwalił ustawę delegującą w sprawie autonomii finansowej, otwierającą pełną drogę do realizacji zasady federalizmu fiskalnego, w wyniku której rząd miał przygotować osiem dekretów (s. 279). Autor wspomina tutaj o fakcie wydania dopiero pięciu dekretów. Dodać należy, że do momentu ukazania się książki na rynku wszystkie osiem dekretów zostało już wydanych i weszły one w życie.

Stosunkowo krótki rozdział XV prezentuje zagadnienie stanów nadzwyczajnych, którego objętość jest zdeterminowana niezbyt obszerną regulacją tej w Konstytucji Włoch. Analizując rozwiązania konstytucyjne wprowadzania stanów nadzwyczajnych, Autor koncentruje rozważania wokół zróżnicowanej roli rządu i prezydenta w sferze zapewnienia bezpieczeństwa państwa.

Doskonałym dopełnieniem rozważań jest kolejny, rozdział XVI, który poświęcony jest ważnym zagadnieniom obecności Włoch w Unii Europejskiej. Autor dokonuje tu analizy podstawowych czynników kształtujących etapy integracji europejskiej. Zdaniem Autora, do najważniejszych kwestii w tej materii należy zaliczyć art. 11 Konstytucji Włoch, który już na etapie tworzenia ustawy zasadniczej odnosił się do problematyki umocnienia pozycji organizacji międzynarodowych, które są konieczne dla wzmocnienia różnych inicjatyw politycznych i ekonomicznych i dla zapewnienia im poparcia ze strony społeczności międzynarodowej (s. 291).

Uwagę czytelnika niewątpliwie wzbudzi rozdział XVII, który analizuje zjawisko mafii we Włoszech. Charakteryzując problem Autor przedstawił historię mafii i podjął się trudnej próby wskazania przyczyn jej powstania. Wskazując na zachodzące procesy przemian w obecności zjawiska mafii we Włoszech w konkluzji Autor stoi na słusznym stanowisku, iż „mafia jest nadal najpoważniejszą chorobą Włoch” (s. 313). W tej części opracowania autor w przejrzysty sposób wyróżnia etapy powstawania i obecności mafii na ziemi włoskiej.

Książkę zamykają uwagi końcowe, które zawierają krótką analizę obecnej sytuacji politycznej Włoch, trafnie wskazując na potrzebę dokończenia rozpoczętych w 1993 roku reform instytucjonalnych. Nie sposób nie zgodzić się 
z tezą Autora, iż włoska scena polityczna jest mało stabilna i charakteryzująca się częstymi zmianami rządów.

Na uwagę zasługuje fakt, że Autorzy starannie zgromadzili literaturę przedmiotu, podstawowym jej trzonem świadomie czyniąc literaturę polskojęzyczną, obejmującą najnowszy dorobek nauki w tej dziedzinie. Nie bez znaczenia, co należy z całą mocą podkreślić, są też umiejętności lingwistyczne i translatorskie, pozwalające Autorom na zapoznanie się bezpośrednio ze źródłami włoskojęzycznymi. Ponadto, co warto zauważyć w każdej części opracowania formułują oni własne oceny i poglądy.

W podsumowaniu należy podkreślić, że książka A. Gacy i Z. Witkowskiego stanowi ważną i ciekawą pozycją zarówno pod względem naukowym, jak i poznawczym, dotyczącą systemu konstytucyjnego Republiki Włoskiej. Książka została napisana klarownym językiem i oparta została na bogatej literaturze przedmiotu. Zamieszczony na końcu każdego rozdziału wykaz literatury może być cenną wskazówką dla wszystkich, którzy chcieliby pogłębić swoją wiedzę o ustroju konstytucyjnym Włoch. Niewątpliwym autem recenzowanej książki, który należy podkreślić, jest jej aktualność, bowiem obejmuje ona swoim zakresem bieżące wydarzenia polityczne we Włoszech, mające wpływ na praktyczne funkcjonowanie ustroju konstytucyjnego tego państwa. Z całą pewnością recenzowana książka stanowi pozycję niezbędną nie tylko dla osób zainteresowanych problematyką przemian konstytucyjnoprawnych i politycznych we Włoszech, ale również dla tych, których zainteresowania badawcze i naukowe wykraczają poza tę sferę.

Monika Urbaniak (Uniwersytet Medyczny w Poznaniu) 